\title{
Notes towards a History of Khoi Literature
}

\author{
Hermann Wittenberg
}

\begin{abstract}
:
This article puts forward a revisionist history of Khoi literature, and also presents a number of translated Khoi narratives that have not been available in English before. Compared to the large volume of Bushman literature and scholarship, there has been very little Khoi literature and engagement with it, and an argument is presented to account for this gap in South African cultural history. Until now, the major source of Khoi literature was Wilhelm Bleek's Reynard the Fox in South Africa (1864), and this text is critically interrogated as a limiting version of Khoi orature. An alternative corpus of Khoi narratives is presented that was originally published in Leonard Schultze's Aus Namaland und Kalahari (1907).
\end{abstract}

Keywords: Khoi literature, Bushman literature, orality, W.H.I. Bleek, L. Schultze, translation

\section{A Brief History of Khoi Literature}

Compared to the wealth of scholarship and literary engagement with Bushman ${ }^{1}$ culture and orature, it is remarkable how little we know about the indigenous Khoi literatures of Southern Africa. Wilhelm Bleek and Lucy Lloyd's Specimens of Bushman Folklore (1911), and the 12000 page /Xam notebooks from which the publication derived, have had a massive impact on current scholarship and popular writing, an interest that culminated in Pippa Skotnes's landmark "Miscast" exhibition (1995), but which has since continued to generate a large volume of academic studies by historians, anthropologists and literary scholars. The Bushman archive has also spawned numerous imaginative interventions, ranging from Stephen Watson's Return of the Moon (1991) and Antjie Krog's more recent the stars say 'tsau' (2004), to a wide range of popular adaptations for children.

In view of this wealth of Bushman-inspired material, the paucity of Khoi primary records as well as scholarly commentary and creative engagement represents a significant gap in South African cultural history. Like Bleek and Lloyd's /Xam culture, the eleven Khoi languages of Southern Africa are also now extinct, with the exception of Nama (Traill, 2002: 27). This gap is all the more remarkable given the emphasis in postcolonial theory generally, and in post-1994 revisionist thinking more specifically, on a recovery of the indigenous voice. Not that the Khoi have been ignored in history and in colonial letters. As J.M. Coetzee has shown in a well-known essay "Idleness in South Africa", the Khoi, or to use colonial parlance, the "Hottentot", figured prominently 
colonial travel writing and Cape discourse, though primarily as a stereotypic figure of disparagement (1988: 12-35). Some significant Khoi figures such as Krotoa/Eva and Sarah Baartman (the "Hottentot Venus") have recently received much revisionist attention, particularly by feminist scholars (for example Samuelson 2007), but evidence of Khoi self-representation in the form of a literary record is scant. This is surprising, given their status as South Africa's first indigenous people to come into contact with colonial literate cultures, a sustained and often intimate contact that stretched over 200 years from at least the late $16^{\text {th }}$ century until the 175 os when a coherent and distinctive Khoi culture can be understood to have largely disintegrated (Elphick 1985: xvii). Khoi languages persisted on the colonial fringes such as the eastern and northern Cape for another hundred years, but it is only in the remote Richtersveld and southern Namibia that one of the Khoi languages, namely Nama, is still spoken today.

But even in mediated form, examples of Khoi voices in the literary record are rare, if we look at the solitary example of Andrew Bain's coarse and caricature figure of Kaatjie Kekkelbek (1838). For Michael Chapman "it would take Lena - in Athol Fugard's Boesman and Lena (1969) - to restore human speech to the caricature of the Hottentot" (2003: 33). Chapman's only cited example of an authentic Khoi voice is even later, dating from the 1980s: it is Piet Draghoender's lament, recorded in the Kat River area by the oral historian Jeff Peires (2003: 34-35).

The major source of Khoi literature therefore remains Wilhelm Bleek's Reynard the Fox in South Africa; or, Hottentot Fables and Tales, published in London in 1864. As Bleek put it himself in the preface to the slim volume, he had written "in 1861, to different Missionaries in South Africa, requesting them to make collections of Native Literature" (1864: xi). Together with a few stories culled from even earlier travelogues such as James Chapman's Expedition of Discovery into the Interior of Africa (1838), 42 of these transcribed and translated oral narratives were published, making the Reynard volume the first published book of indigenous literature. Khoi literature, in its published form, thus not only precedes the publication of Bushman literature, but also comes well before Olive Schreiner's Story of an African Farm (1883), which is conventionally regarded as the work that inaugurates South African English fiction.

The singular achievement of Bleek's book must be judged against the dominant attitudes of the time, which Tony Trail characterizes as an "extreme linguistic prejudice": from the first contacts between Europeans and Khoekhoe there had been a persistent attitude on the part of the Europeans that the language was utterly bizarre, unpleasant, inarticulate and not human (2002: 32)

Against this colonial structure of feeling, Bleek's interest in Khoi language and folklore must be regarded as progressive and enlightened. So singular is Bleek's work, that other

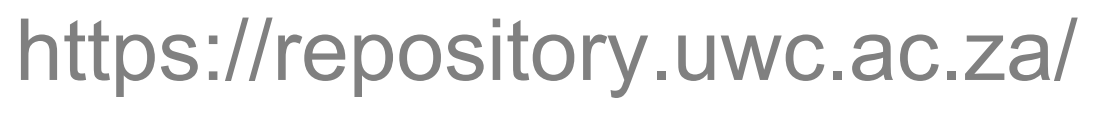


published instances of Khoi voice have had to rely on his pioneering book. Five short Khoi poems in the Penguin Book of Southern African Verse (Gray 1989: 33-34) are extracted from the Reynard book, and in the anthology SA Poesie / SA in Poetry (Van Wyk et al, 1988) there are three short versifications based on extracts from Schapera's The Khoisan Peoples of South Africa. Bushmen and Hottentots (1930). Schapera, in turn, used Bleek's records as a source. There are five short animal stories (of which two are of Tswana origin) in L.F. Maingard's Korana Folktales (1962). These narratives were, as he recounts,

dictated to Dr Lucy Lloyd, 1879, by //oãxab=/=xam or Piet Links, who belonged to the kei! Korana (the great Korana) or Taaibosch tribe. He was born at Mamusa (the modern Schweitzer Reneke), the seat of the tribe, and wandered from there to Kimberly. After the defeat and dispersal of the Taaibosch at the battle of Mamusa, the tribe ceased to exist (1885). From Kimberley, he and his family mistaken for Bushmen, were sent to Dr Lloyd in Cape Town. (1962: iii)

Maingard's narrative of confused ethnic identity confirms again that it were the Bushmen, rather than the Khoi that were to become the primary object of scholarly interest. For Bleek, the Bushmen could be regarded as an original first people, in whose language and culture perhaps were traces of humanity's lost beginnings. By the time he was working with his Breakwater informants in the late $19^{\text {th }}$ century, the descendants of the Cape Khoi were not a remote, exotic culture, but had become largely assimilated into domestic service, forming an ever-present urban and rural underclass that had become part of everyday life in the Cape Colony. The Bushmen, on the other hand, came from the remote fringes of civilization, and their rarity and near extinction excited his Bleek's imagination. This is how he put it in a letter to the governor of the Cape, Sir George Grey in 1873:

You can fancy that the rare and difficult opportunity of having it within my reach to discover not only a language almost unknown, but still more to rescue portions of a rich and highly important folklore belonging to so primitive and in the point of civilization so low a race, dared not to be neglected by me. (Spohr 1962: 37)

In the 1870s, until his premature death, Bleek consequently focused all his energies on a rapidly vanishing Bushman culture, and his Khoi research would remain confined to the Reynard book.

Despite the significance then of the Reynard volume as a valuable and unique record of Khoi oral tradition, Bleek's approach to indigenous orature is however also emblematic of the "processes of exclusion, occlusion and effacement that have occurred in the construction of the cultural history of this country", as Duncan Brown has put it in his

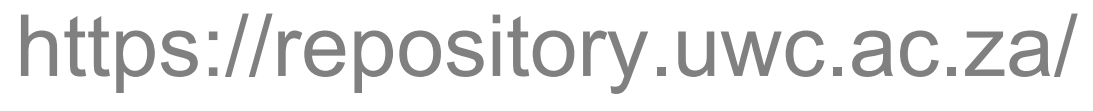


introduction to Oral Literature and Performance in Southern Africa (1999: 4). Bleek, as I have shown elsewhere, ${ }^{2}$ suppressed the erotic and sexually explicit aspects of indigenous narration, trapping Khoi orature in an immature cultural space that could not admit any adult, mature content. As Bleek himself put it in the preface, to make these Hottentot fables readable for the general public, a few slight omissions and alterations of what would otherwise have been too naked for the English eye were necessary. (1864: xxiii)

Bleek was not only constrained by his Victorian morality and prurience that could not admit any erotic and scatological material, 3 but his editorial interventions must perhaps also be understood as a progressive, enlightened attempt to elevate the figure of the "Hottentot" from the its well-established negative associations in colonial Cape discourse with disorderliness, indolence and licenciousness. By framing South African indigenous narratives within the generic conventions of the naïve European children's fable, Bleek was thus attempting to civilize the Khoi imagination.

\section{Leonhard Schultze's Khoi Researches}

The fourteen narratives presented here are an initial attempt to recuperate Khoi orature from these restrictive cultural politics, and allow an alternative insight into a narrative world less tainted by the operations of colonial censorship. The source of these narratives is a little known German scientific treatise written by Leonhard Schultze, titled Aus Namaland und Kalahari (1907). It contains a corpus of 67 tales, as well as proverbs, riddles and songs, collected during a scientific expedition to southern Namibia and the Northern Cape in the years 1903 to 1905.

Leonhard Schultze (1872 - 1955)4 trained as a zoologist under Ernst Haeckel, Germany's leading exponent of Darwinian evolutionary theories, but was appointed as an extraordinary professor in Geography at the University of Jena. Subsequent to his African expedition, he held a chair at the University of Marburg and conducted major ethnographic and linguistic research in Meso-America. Schultze was a brilliant scientist, and worked effortlessly across several disciplines in order to produce a synthesized account of the "Gesamtnatur" of a given country. His research expedition was funded by the Humboldt Foundation, and Aus Namaland und Kalahari takes a Humboldtian approach by describing the country's geology, climate, plants, animals and people in a broad, panoramic sweep, blending empirical rigor and carefully observed detail with occasional lyrical passages. His perceptive eye and keen interest in people was not only limited to ethnographic description of the various indigenous groups, but also produced critical observations of colonial German foibles and failings:

We have to admit openly by now that the Hottentot knows us better than we know him ... He never loses interest in studying the white invader. (1907: 174)

\section{https://repository.uwc.ac.za/}


Schultze's understood his research into Khoi culture and language as a means to rectify this imbalance, and was primarily through the folktales that a detailed and in depth insight into the very essence of the subject people was possible. As Schultze put it, "These texts are the title deeds to the soul of the Hottentot, which need to be decoded." (1907: 390) Because of the outbreak of the Herero and Nama war at the beginning of 1904, Schultze's exploratory zeal was severely curtailed. Displaced by the conflict to Klein Namaland (the area of the northern Cape Colony south of the Orange River), he worked ethnographically in the area of Steinkopf and Springbok for most of 1904, learned the difficult Nama language, and presumably collected many of the tales. By the beginning of 1905, Schultze sought to extend his researches to Great Namaland (north of the Orange River) but it was here that the German Imperial Army was waging a major campaign against the Nama. Schultze accordingly attached himself to the armed forces of General Lothar von Trotha headquartered in Keetmanshoop, repaying the hospitality and supply of armed escorts with part-time work as a war correspondent. Trotha was also generously thanked in the preface of the book. After the last major flanking maneuvers against Hendrik Witbooi, Schultze was given an armed escort taking him westwards into the Kalahari.

In recent revisionist scholarship, the brutal Herero and Nama extermination wars are now recognized as Germany's first exercises in genocide. As recounted in a recent survey article of these studies by Mohamed Adhikari (2008: 317), the Nama lost 50\% of their population following Trotha's notorious annihilation warfare. What is extraordinary about Schultze's ethnographic work undertaken during these genocidal military campaigns, is that it reflects none of the unprecedented violent trauma which would have been the unavoidable context of the narration of these tales.

A paradoxical picture however emerges of Schultze's colonial ethnography: on the one hand he was Trotha's complicit embedded scientist who utilized the victims of war, both the dead and imprisoned, as convenient subjects for study. But on the other hand, Schultze's efforts to learn the difficult Nama language with its complex plosives and clicks, and his painstaking method of transcription and exact, grammatically annotated word for word translation, reveal not only a man of extraordinary listening skills, but also someone who displayed a genuine respect for and engagement with the culture and language of his informants. The sheer volume, the detailed annotations and moreover the candid content of the narratives suggest a close, intimate and mutually trusting relationship between himself and the people who gave him the gift of their stories.

In trying to make sense of Schultze, it is tempting to contrast the day-time positivist scientist with the night-time sympathetic listener, who allowed himself to be lured away from the measurable certainties of quantitative knowledge into a magical world of nocturnal story-telling. During the day, Schultze employed his methodical gaze in the

$$
\text { https://repository.uwc.ac.za/ }
$$


collection of scientific data, making precise measurements and taking anthropometric photographs which reduced the surface of the native body to a series of numbers and mathematical ratios. But at night, around the evening camp fires, Schultze appeared increasingly drawn to the inner, imaginative world of his travelling companions. In such an intimate context under a familiar night sky, surrounded by a land that was their own home, the Khoi could engage in a revelatory form of story-telling that was open to the free flow of risque jokes, and earthy, racy content. Unlike the narratives collected by Bleek and Lloyd from Bushman prisoners in artificial constrained circumstances, the stories that Schultze recorded were primarily performed by and for the other Khoi listeners who accompanied the research expedition as mule drivers, cooks and guides. The researcher himself sat quietly taking notes in the background:

What I had listened to at night around the fire, I had repeated to me slowly the next day by the story teller, so that, after some practice, I was able to obtain a coherent dictation. In order to ascertain if the act of dictating had disturbed the sentence structure and sequence, I asked the Hottentot to repeat his story at normal speed and carefully noted down variations. (1907: 752)

Comparing his stories with those assembled by Bleek in the Reynard volume, Schultze's conclusion about their ethnographic veracity was contemptuous: "Bleek's stories do not reveal to me the Hottentot whom I have gotten to know. Since I was able to tap into the very source of their lore, I will disregard his versions completely" (1907: 389). Schultze's Khoi stories, as will become immediately apparent, are told in a very different register than Bleek and Lloyd's material.

\section{Methodological reflections}

In keeping with the philological paradigm of the period, Schultze transcribed the Khoi stories in an exact and precise manner as possible, using an orthography of his own invention that rendered the various click sounds and intonation variables as faithfully as possible. Unlike Bleek and Lloyd's Specimens of Bushman Folklore that was only published four years later, Schultze did not follow a side by side presentation of original and translated texts, but used a sequential method. Following the Khoi text, is then a German translation that attempts to keep to the original word order, and is liberally interspersed with parenthetical grammatical glosses. A distinguishing feature of Khoi narration, namely the pervasive use of the passive voice, for example remains visible. With all the meticulous and detailed annotations, the translated texts are often more than twice the length of the original, making for a cumbersome reading experience. Schultze's translation method was less aimed at producing a coherent and fluent German-language narrative, but to provide an exact, verifiable rendering of the original.

\section{https://repository.uwc.ac.za/}


In contemporary translation theory, the elusive goal of absolute equivalence between original and translated text is no longer regarded as attainable or desirable, and the word for word paradigm employed by Schultze (as well as Bleek and Lloyd) is no longer accepted as an appropriate way to translate oral narrative. I have therefore followed Harold Scheub's counsel that

one of the greatest injuries that can be done to the original work is simply to 'retell' it without making any effort to give it a dynamic and artistic content. (qtd in Biesele 1993: xii)

My translation of Schultze's German versions has therefore been somewhat freer, but always adhering to the original content. In the case of sexual terminology and vulgar language, an approximation of the plain, direct language of the original has been preferred to more polite circumlocutions or Latinate euphemisms: thus "shit" instead of "faeces" or "excrement". The word "penis" has been reluctantly used instead of more colloquial English synonyms, since all these variants have connotations that seemed inappropriate for the narrative context. Occasionally I have consulted Nama dictionaries where Schultze's translation seemed suspect, and square brackets indicate where extraneous explanatory material has been inserted.

The selection from Schultze's 67 tales has been guided by the following criteria. Firstly, stories were chosen that had not been published in a variant form in Bleek's Reynard book, nor in Maingard's Korana Folktales. Both Maingard's three Khoi stories and at least a third of Bleek's 42 "fables" have a close correlate in the Schultze corpus. Some examples of stories which can be regarded as closely related, or even, in some cases, almost identical are as follows: "Hunt of the Lion and Jackal" (Bleek 3) and "The Lion and Jackal" (Schulze 489); "The White Man and the Snake" (Bleek 11) and "The Snake which was rolled over by a Stone" (Schultze 491); "Fish Stealing" (Bleek 1) and "The Jackal who lies next to the wagon" (Schultze 464); "Cloud Eating (Bleek 14) and "The Hyena and Jackal jump up to the Clouds" (Schulze 460); "The Cock" (Bleek 23) and "The Jackal who tricked the Flamingo and the Hen" (Schultze 483); "The Zebra Stallion" (Bleek 39) and "The Zebra Mares and the Baboon" (Schultze 535). In comparing many of these tales, the differences between Schultze's "naked" and uncensored versions, and Bleek's sanitized adaptations are of course noteworthy, but I have here wanted to present new material.

Secondly, tales from Schultze's collection were chosen to illustrate the various categories of narratives, giving the reader a representative selection of the corpus. Apart from several animal stories, there are thus three tales which feature the Aigamuchab, who is a well-known ogre figure in Khoi mythology, recognizable by the eyes on his feet. When the Aigamuchab manages to pick out the choice fatty cuts of meat on the plate although they are turned upside down, his canny companion suspects that he may be looking up

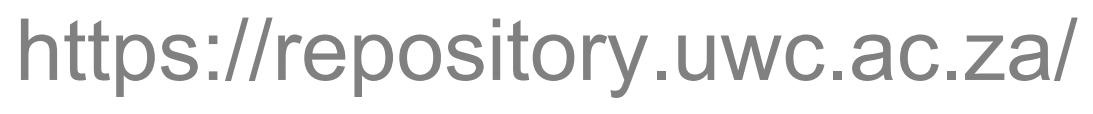


at the meat from below, and so the fact that his eyes are on his feet is revealed. In this and a couple of other narratives, the wily jackal is a central figure. He is an attractive and entertaining trickster figure in Khoi orature, who even manages to outwit lions, hyenas, leopards and people. Three of the tales also feature Boers, showing clearly that Khoi orature was not locked in a time-less pre-colonial world, but had adapted to historical and social change. In one of these stories, "The Jackal who sold a Horse to the Boers", the jackal outwits a greedy but dimwitted Boer who eventually, once the penny has finally dropped, retaliates with characteristic and unrelenting violence. In stories such as this, the antics of animal proxies in Khoi folklore do not only reveal deep insights into human psychology, but are also a window into the fraught colonial relationships between settlers and indigenous peoples. Living on the fringes of a new colonial monetary economy that was beginning to replace the traded exchange of goods, the Khoi here mock the new forms of value by conflating money with "shit".

Even the missionaries and their Christianity are the butt of subtle satire, for example in the story "The Two Brothers" : the Christian ritual language of thanksgiving ("The Lord has given us water!" ; "The Lord has provided us with food!") is discredited and perverted in the mouths of murderous robbers, who moreover mistake human urine and excrement for divine nourishment. The word of God is a load of "shit", if we follow the language and logic of this Khoi narrative. The Khoi were however not only the recipients of violence in the form of an encroaching colonial order, but had themselves subjected the Damara people to their rule. A number of stories deal with the uneasy and often violent relationship between the Khoi and their Damara subject people, such as the story of the Damara boy who escaped being killed.

Even a cursory look at these narratives reveals that sexual and scatological content forms an integral part of the imaginative and story-telling universe in Khoi orature. Rich expletive insults such as "You dirty pus-encrusted dick head" (original 'kya !haî !garaba', transl. by Schultze as 'Schmutzkrusten Schamkerl!' 481) are frequently used in the narratives. A good example of unrestrained erotic story-telling is the narrative "The Jackal and the Two Girls" in which fantastical magical transformations allow the liberated, disembodied penis free access to penetrate a reluctant girl. Stories such as these should however not lead us to a simplified conclusion that Khoi culture was given to sexual or moral wantonness. Marital fidelity is the major theme in the first story, "The People who collected Reeds", where the faithful persistence of conjugal love leads to a happy ending. In the next story, "The Girl who insulted the Damara", shame and nakedness play a pivotal role, and the precocious girl who transgressed the behavioral code is punished by being deprived of her clothes - and her brothers cannot rescue her until they cover her nudity with ash.

\section{https://repository.uwc.ac.za/}


Altogether, a reading of the Schultze corpus of tales against Reynard shows the normalized and natural presence of "naked" elements in the Khoi narratives where no part of the anatomy is taboo. Bodily functions, excrement and violence are a natural, uncensored part of the story-telling world and it is not surprising that such "naked" tales would not have found an appreciative audience in Bleek's Victorian society. The dominant picture that we have of the Khoi (and Bushman) imagination is one that has been shaped by Bleek's editorial interventions; the sample of Schultze's translated tales presented here for the first time in English therefore offers us a fuller, more comprehensive picture of a richly imaginative indigenous culture.

\section{Selections from Leonhard Schultze's Nama Tales}

\section{The People who collected Reeds}

A man had taken a wife. Together with his brother and his wife, the three of them went riding out on an ox looking for reeds to make sleeping mats. When they came to the water they unsaddled the ox, and the two men went away to cut the reeds. The woman however went to the water to wash herself. And as she was washing herself, a frogwoman appeared and put on the clothes of the woman. She said: "Frog, take off those clothes!" But the frog replied: "No, sister, I am only trying them on." And when the woman had finished washing herself, she said: "Give me the clothes back now, frog!" But the frog fled and went to the place where they had unsaddled the ox. The woman was ashamed and hid in the bushes, and the man took the frog as his woman, thinking that the frog was his wife.

But when the people go out looking for reeds, the true wife comes and sweeps the hut, cleans the pots, grinds the buchu, makes butter in the calabash, and gives milk to her old blind mother-in-law. Then she goes away again. One day the old woman spoke to her son and said: "Hide yourself in this grass mat, lie down quietly rolled up in it, and try to see which person always comes here." And while he lay hiding, the woman came. She sat down, took the calabash and while she was making butter he spat at her. She fled, but he ran after her and caught her. She then said: "Go to your frog-wife, you, who have married a frog-woman, and has abandoned me!" But he caught her again and wanted to take her back to the hut to have her again.

In the mean time the frog-wife and the man's brother arrived on the ox. The frog-wife commanded the husband to help her and spoke: "Take me down!" But no one answered her. He then took his leather whip and lashed her. She jumped down from the ox herself and called out: "I am a frog! I swim in the waters!" So she spoke and jumped into the water. And the man who had found his wife again, married her again. (432-434)

\section{https://repository.uwc.ac.za/}




\section{The Girl who insulted the Damara}

A Damara man once came to a hut and as he sat down at the door, a girl [peering under his loin-cloth] said to him: "Like that calf in front of my mother's hut, as misshapen and gross is your penis." And she took ash out of the fire place and threw the ash over him. The older girls said to the girl: "Know that he is a grown up man." He however answered: "Let it be, she talks so out of ignorance, let her go."

And on the next morning, early, the girls all went swimming. When they had undressed and had gone down into the water, the Damara came and took away their clothes. And only when they came out, they saw the man. They went to him and said: "Dear old father, give me back my embroidered hind loin cloth and my front loin cloth, all of it!" And he gave it all back to them, but to the girl who had insulted him he said: "First run and pick thorns from that thorn tree which stands over there." So she ran and brought them to him. The Damara however grabbed her and stuck the thorns hard into her, joining her limbs, and she could no longer move her body. Then he picked her up and threw her into the thorn bush.

Then her people came past and the first ones to come past were the grandparents. So the girl called: "My grandparents, see, the roots [spikes?] of the thorn tree are holding me down." But the grandparents answered: "Had I not told you, girl, 'Pour some water for me', and you did not listen?" So they spoke and went away.

Then the two servants of her mother came past, and the girl called out: "Oh servants of my mother who are walking past, see, the roots of the thorn tree are holding me down." But they answered: "Did I not tell you, girl, to milk the cow so that I can mix in the water, and you did not do this?" So they spoke and went away.

Then the parents came by, and the girl called out: "Dear parents who are walking past, see, the roots of the thorn tree are holding me down." But they answered: "Did I not tell you, girl, to clean the hut, and you did not do this?” So they spoke and went away.

Then the sisters came by, and the girl called out: "Dear sisters who are walking past, see, the roots of the thorn tree are holding me down." But they answered: "Had we not told you: 'Know that he is a grown-up man?"' So they spoke and went away.

Then her two brothers came, and the girl called out: "My brothers who are walking past, see, the roots of the thorn tree are holding me down." They ran to her [and when they saw her nakedness] they threw ash on her [to cover her shame], and then hauled her out. The brothers then sat behind the tree and a bitch pulled out her thorns. And when the dog had all her thorns pulled out, they all went away. (434-436)

\section{https://repository.uwc.ac.za/}




\section{The Man who went walking to the place of the Damara}

A Nama man once came to the place of the Damara people and was given a dish of mice [a prized meal among the Damara] and wild onions; thus he was served. But although it was late and the people were ready to go to bed, he still stayed up.

Then the Damara woman asked: "Hey, why are you still sitting up after I have given you wild onions and mice, and have served you so well?" And he answered: "Oh, I am hungry for that which through sitting on it becomes soft."

So she called her daughter and said: "Take this man, and you [speaking to the man] do not put your whole thing inside, for she is a young, small girl." But he did go in completely. The girl then cried and the old woman said: "Have I not told you: "Young is this girl, do not go in completely with your thing!" So she spoke and took the girl away. (430)

\section{The Damaras and the Namas}

The Damaras lived in a far-off place. One day the Namas went to their place to kill the Damaras. On that day they had all gone out to collect wild onions, but had left a small boy behind. While this Damara boy was all alone at home, the Namas came.

Some of them said: "Let us kill this Damara!" So they spoke. Others said: "Why, what can such a Damara boy do who is sitting with his bum in the onion peels?" The others replied: "Let us kill him, he might tell tales!" But the others said: "This little Damara boy is too young, he won't say anything." So they left him and went to wait in a hide, and lay down there.

While they were lying down and sleeping, the other Damaras returned. The small Damara boy continued to pick onion peels from the ashes and sang:

"Let us kill him!" spoke some of them.

"Why, what could he do, this little one with his butt in the onion peels!" said the others.

"Tell tattle tales, he will," they said.

"Just look at this young Damara!" said the others.

"Big enough is he!" they said.

"He is just a stupid Damara!" said the others.

Then the mother asked: "What is this little one saying?" But he continued picking onion peels from the ashes. Then the mother threw down her wild onions, and the boy told her everything and she told the others. The women, children and old people of the Damaras

\section{https://repository.uwc.ac.za/}


went away to hide, and the young men remained there. They then went to the hide and put fire to it. It started to burn, and the bullets and the guns burned. And all the Namas died. (422-423)

\section{The Two Brothers who drove calves}

Two brothers once drove calves into the fields. There they found a goas plant, and while they were busy with it, they met a woman. And the woman gave them a spike, and took the goas plant. Then they both went away.

They met a man, a man who was trying to prick out a thorn from his foot by using his penis. The two brothers said: "We have a spike, while uncle is trying to remove the thorn with his penis." And they gave him their spike, and the man gave them a walking stick. Then they came past some boys who were using a stone to dig out honey from a tree trunk. And they gave them the stick, got some honey, and went on.

They came to some guinea fowls who were eating wild onions on the field, and spoke: "We have honey while you are eating wild onions." They replied: "Well, give us some then!" It was given to them, and the brothers went on. They had gotten some feathers in exchange.

Then they met some boys who were feathering their arrows with sheep's wool, and spoke to them: "We have feathers but despite this you feathering your arrows with sheep's wool?" They then replied: "Well, give us some then!" Then the two brothers left; the boys had however given them milk.

Then they came to a bitch who was eating shit. And they said to the dog: "We have milk while you are eating shit." And the dog said: "Why then, give me some!" So they gave her the milk, but when the time had come for them to go they thought to themselves: "What will be given to us?" and spoke: "We got the milk from the boys and gave it to you, now we want something!"

[The story ends at this point and it is understood what the duped brothers would have gotten in exchange] (415-416)

\section{The Two Brothers}

There were once two brothers who were herding cattle. The older one went away looking for food while the cattle were being looked after by the younger one. While he was walking back with a bowl full of food, he saw his own shadow and spoke: "What do you want?" and gave the shadow a piece of meat and went on.

\section{https://repository.uwc.ac.za/}


But when he turned around again, he again saw his shadow and said: "Hey, you, this is not my food to give away!" So he spoke, gave the shadow another piece of meat, and then continued on his way.

And again he turned back and said: "You keep following me for this food, which is not even mine! Take the whole bowl with everything in it, but leave me alone!" So he spoke, gave up the whole bowl, and went on.

When he came back, his brother said: "Where is the food?" And he answered: "That person there has finished everything." The other one said: "You fool, that is only your shadow!" and went away.

And while he was gone, the other one cut the throats of all the cattle. When the brother came back he asked: "Why did you cut the throats of all the cattle?" But he answered: "They did not want to stay put, that's why I cut their throats, oh I was too tired to keep on running after them." The other one said: "You have done a big thing here [that will bring trouble]. Let us quickly run away!"

So they went and got to the place of a Boer. He saw some fat in a jar and put his hand inside, but the jar would not allow his hand to come out again. So he hit it on a stone, and it broke. They went on.

And they came to a large tree, and saw men coming who were killing people and robbing them. They quickly climbed up the tree to hide. But the robbers, who were very thirsty, also came to the tree to rest in the shade. The boy then peed down on them, but they said: "The Lord has given us water!" and they drank it. Then the boy shat down on them, but they said: "The Lord has provided us with food", and they ate.

Then they took out their money and spread it on skins to count it. The boy threw down a heavy branch, and they called: "The Lord is punishing us!", left their money lying there and ran away. The brothers climbed down, took the money and went on.

The older brother was told by a Boer to carry away a calabash. "Three pieces of money I will give you," he was told. And as he was walking away, he said to himself: "When one day I will have my own son, I will call him my first-born and he will get a piece of that money. The second son will get the second piece of money, and the third one will get the third piece. And if I have a fourth son I will chase him away with this calabash!" And as he spoke, he swung the calabash wildly, so it broke. He however was caught by the Boer. (443-445)

\section{https://repository.uwc.ac.za/}




\section{The Lions who pretended to be dead}

Two lions who were travelling were tired and they saw a jackal approaching. [Not wanting the trouble of a hunt] they lay down pretending to be dead, and the jackal came closer. He quietly crept up and softly touched the back hole [anus] of the one lion, and saw how it contracted. Then he knew that they only pretended to be dead and said: "Thank you Lord, that you have given me this food!" Then he made a fire with some grass and said aloud: "Let me first find some fire wood," and he went off. And while he was breaking off wood, he gradually went further and further away, and once he had escaped he climbed on to a rock and called out: "Luckily I touched your arseholes! You stupid, dirty, pus-encrusted dick heads! You could have almost killed me!" This is how he shouted, but the lions were very tired, and therefore they did not run after him. (486)

\section{The Jackal and the Two Girls}

And that is how it happened: although the jackal had two girls, he only slept with one of them. And because he could not enjoy the other girl, he made a plan. He went hunting and before he left he said to them: "If a springbok comes past here, then you must say: we wish that this springbok would break apart at his thigh bone!" And both of the girls said: "Yes!" To that girl [whom he wanted] he then said: "You will take the private parts when this springbok falls down!"

The jackal went away, changed himself into a springbok, and then ran back to the girls. And as he came past, they called out: "We wish that this springbok would break apart at his thigh bone!" The springbok then collapsed, and the two girls slaughtered him. The one girl however who had not yet been enjoyed by the jackal, took the private parts of the springbok, and cooked that meat on the fire. She then ate all the fat, and truly ate up all the fat there was. Then she laid the cooked penis of the springbok on a flat stone and pounded it until it was soft. But the penis jumped up and entered her; she pulled it out, and again she pounded it on the stone. But up again it jumped and came into her, and the jackal [taking back his former shape] called out triumphantly: "The one who has never been enjoyed by me has now been enjoyed!" (494-5)

\section{The Jackal who sold a Horse to the Boers}

The jackal sold a horse to the Boers but beforehand he put some money into the horse's back hole. He then led the horse to them and said: "Now I will first get some money from that horse!" And when the horse shat, he held his hand underneath, and they could see that the horse was shitting money.

When the two Boers spoke about the price of the horse, the jackal said: "I cannot put a price on this horse because I will not sell it. But any man would give me a wagon and its span of oxen for it."

\section{https://repository.uwc.ac.za/}


The Boer gave him a wagon with a span of oxen. The jackal spanned in the oxen, climbed the wagon and said: "Boer, wait for three days and the horse will shit money!" Thus spoke the jackal and he rode away.

The two Boers however waited, and when the third day had passed, they waited until the fourth day. But the horse shat no money. Then they saddled their horses and gave chase. They came to a place next to the road and asked: "Where is the wagon that came past here?" "The day before he came past," they were told.

They rode on and came to another place and asked: "Where is the wagon that came past here?" And the people told them: "Yesterday it came past here."

They rode further and came to another place and asked: "Where is the wagon that came past here?" And the people told them: "This morning it came past here."

So they rode further and when they came to the jackal's place they called: "Uncle Fox, I will shoot you through your head!"

The jackal replied: "What have I done wrong that you want to shoot me?" The Boer said: "You told me that the horse which does not shit money, shits money!"

But the jackal replied: "No, do not speak to me so rudely! My older brother traded with you, not I."

The Boers asked: "Where is he?" And the jackal replied: “There, further down that way is his place." So the Boers went away to the other jackal who was innocent in order to shoot him dead. (470-472)

\section{The Jackal who licked out the pot}

The jackal left his place to go to the huts of the people, entered a hut and licked out all the fat in the pot. But the people came back while the jackal was still inside the hut. The man who was the master of the hut asked: "From which place are you, jackal?" The jackal answered: "I am the jackal from the Arobush River. The fruits of the aro-tree I eat, the fruits of the hari-bush I eat, and the fruit of the au-bush I eat, oh yes!"

Then the man said: "Let me see you shit!" This he asked and the jackal shat aro-berries.

Then the man asked: "From which place are you, jackal?" The jackal answered: "I am the jackal from the Arobush River. The fruits of the aro-tree I eat, the fruits of the haribush I eat, and the fruit of the au-bush I eat, oh yes!"

And the man said: "Let me see you shit!" This he asked and the jackal shat hari-berries.

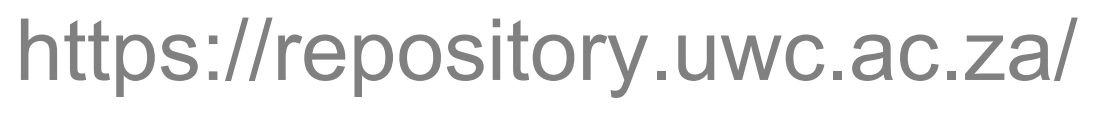


The man asked again: "From which place are you, jackal?" and the jackal replied: "I am the jackal from the Arobush River. The fruits of the aro-tree I eat, the fruits of the haribush I eat, and the fruit of the au-bush I eat, oh yes!"

And the man asked again: "Let me see you shit!" This he asked and the jackal shat auberries.

And again the man asked: "From which place are you, jackal?" The jackal answered: "I am the jackal from the Arobush River. The fruits of the aro-tree I eat, the fruits of the hari-bush I eat, and the fruit of the au-bush I eat, oh yes!"

But the man was still not satisfied and said: "Let me see you shit!" Then the jackal shat fat, and the man caught him. But the jackal called: "My uncle, don't grab me like that." And as the man changed his grip, the jackal escaped and called out: "Oh yes, such a one am I." (472-473)

\section{The Steenbok and the Lion}

The steenbok and the lion, they both were out hunting, and met out on the field. The lion said: "What are those little things [the horns] there on your head?"

The steenbok said: "Why, if you would see a human child alone out here, and would want to harm it like you might now want to harm me, I would use those little things on my head to defend myself, oh yes!"

The lion said: "Why don't you run and strike that termite hill over there?"

But the steenbok replied: "You go and strike it first!"

The lion went and rammed his head into the termite hill, but nothing happened. Then the steenbok ran up to it, rammed in his horns, and many broken pieces of termite hill flew about.

The lion noticed this, and he ran away. But the steenbok gave chase and kept stabbing him in his back hole. (511-512)

\section{Aigamuchab and the Jackal}

The Aigamuchab and the jackal, both of them were on their way to another place. They slept for one night on their way and on the next day they arrived.

An animal was slaughtered for both of them and the meat was given to them in a single bowl. The jackal cut off some nice fatty meat, but laid it in the bowl upside down [with

$$
\text { https://repository.uwc.ac.za/ }
$$


the fatty side hidden underneath]. But the Aigamuchab took his meat from these portions. The jackal looked carefully into his face and could not see any eye. And again he cut off some fatty meat and laid it down upside down, but the Aigamuchab again took his meat from these portions. The jackal looked at his face and could not see any eyes.

When the two of them had finished eating, the jackal bent down to look for a piece of wood with which he could clean his teeth. There he saw the eyes and said: "Fill up a pipe for me!" And when a pipe had been filled for him, he quickly sprinkled some tobacco in his eyes and ran away. (412-403)

\section{The woman who was tricked with a dog}

A woman gave birth to a son, but the other woman were jealous, took the child away and laid him down next to the water. Instead of her child, they put a dog next to her. The cast off child was found by an Aigamucha woman who took him and brought him to her own house. During the time that he was with her he grew up to be a man.

On one day that she had gone away, he went to the place of the Boers and asked for advice. The Boers gave him water and chena thorns and a stone. All this was given to him and also two horses. Then he rode away. In the evening when the Aigamucha woman came home and called him it was quiet and no one answered. Then she followed the spoor and had almost caught up with him, calling out to him: "My little Kaffir child!" He answered "Mama!" and let the water flow out. The water became a lake. Then she swam and swam through the lake while he was running away. And again she almost caught up with him and shouted, " My little Kaffir child!" and he answered, "Mama!" and let the stone fall. And the stone became a mountain. And while she was climbing the mountain, he ran away. Then she was gain close to catching up with him, while he was getting closer to the place of the people. And she called out to him: "My little Kaffir child!", and he answered "Mama!" and let fall the chena thorns. While she was pulling out the thorns from her feet, he quickly ran away and came to the place.

The men immediately went out and waited next to the road, waiting for her. And when she came past, they shot her dead. (401-402)

\section{The two women who were taken along by the Aigamuchab}

And this is how it happened; two women were lost. They came to a place where the Aigamuchab was cutting bark-food from the tree. They called: "You person who are chopping the tree, take us to your place!"

The Aigamuchab looked up and said: "Let me show you my place!" And they went. But the fat woman stayed behind; in this manner the two went away, with one of them staying behind.

$$
\text { https://repository.uwc.ac.za/ }
$$


When the Aigamuchab man looked back, he only saw one woman. He asked and the woman answered: "I don't know, she stayed behind." He swore: "Come along, you child of a dirty dick-head! Being twins, you should stay together!"

Then they came to the place of the Aigamuchab. And as they arrived he said: 'What? Never can this thing taste good! Cut her throat! Let us at least then drink the soup [blood] of it!' so he spoke. Then they grabbed her, and cut her throat off. And as she was shitting herself, they called: 'Catch the fat coming out of the back hole!' And they ate it up.

But then he [the Aigamuchab] looked for the spoor, and he came there and found the spoor and caught up with the woman. Then she gave off a rotting smell which smelt as if she was herself decaying. But he said: 'You stink so sweetly rotten, you will be good for my pot, thus it will taste.' And he quickly went looking for his pot. Then the woman got up and ran away. And while she escaped, he came back with the pot, came there and was disappointed and called: 'Oh sweet-stinking one, where have you gone?' And that is how it happened. (396-397) 


\section{Works Cited}

Adam, Thomas. 2005. Germany and the Americas: culture, politics and history. Santa Barbara: ABC-Clio Press.

Adhikari, Mohamed. 2008. "'Streams Of Blood And Streams Of Money': New Perspectives on the Annihilation of the Herero and Nama Peoples Of Namibia, 19041908," Kronos: Journal Of Cape History 34: 303-32

Bain, Andrew Geddes. 1949 (1838). "Kaatje Kekkelbek, or Life among the Hottentots". In Journals of Andrew Geddes Bain. Trader, Explorer, Soldier, Road Engineer and Geologist (ed. Margaret Hermina Lister). Cape Town: Van Riebeeck Society. 193-202.

Bank, Andrew. 2006. Bushmen in a Victorian World: The Remarkable Story of the Bleek-Lloyd Collection of Bushman Folklore. Cape Town: Double Story.

Biesele, Megan. 1993. Women like Meat. The folklore and foraging ideology of the Kalahari Ju/'hoa. Johannesburg: Wits University Press.

Bleek, W.H.I. 1864. Reynard the Fox in South Africa, or Hottentot Fables and Tales. London: Trübner.

Brown, Duncan. 1999. Introduction. In D. Brown (ed.) Oral Literature and performance in southern Africa. Claremont: David Phillip. 1-17.

Chapman, Michael. 1996. Southern African Literatures. London: Longman.

Coetzee, J.M. 1988. White Writing: On the Culture of Letters in South Africa. New Haven: Radix.

Elphick, Richard. 1985. Khoikhoi and the Founding of White South Africa. Johannesburg: Ravan Press.

Jenkins, Elwyn 2010. "San Tales Again: Acknowledgement and appropriation”. In English Academy Review 27(1): 24-35.

Krog, Antjie. 2004. the stars say 'tsau’: /Xam poetry of Dia!kwain, Kweiten-ta-//ken, /A!kunta, /Hankassó and //Kabbo. Selected and adapted by Anjie Krog. Cape Town: Kwela.

Lloyd, Lucy (ed). 1911. Specimens of Bushman Folklore. London: George Allen and

$$
\text { https://repository.uwc.ac.za/ }
$$




\section{Unwin.}

Maingard, L.F. 1962. Korana Folktales. Johannesburg: Wits University Press.

Samuelson, Meg. 2007. Remembering the nation, dismembering women? Stories of the South African Transition. Pietermaritzburg: UKZN Press.

Schultze, Leonhard. 1907. Aus Namaland und Kalahari. Bericht an die königlich Preussische Akademie der Wissenschaften zu Berlin über eine Forschungsreise im westlichen und zentralen Südafrika in den Jahren 1903 - 1905, Jena: Gustav Fischer.

Spohr, Otto. 1962. Wilhelm Immanuel Bleek. A Biographical Sketch. Cape Town: UCT Library.

Trail, Anthony. 2002. "The Khoesan Languages". In R. Mesthrie (ed.) Language in South Africa. Cambridge: Cambridge U.P. 27 - 49.

Watson, Steven. 1996. Return of the Moon: Versions from the //Xam. Cape Town: Carrefour.

\section{NOTES}

\footnotetext{
${ }^{1}$ The use of racial and ethnic terms is contentious in South African studies. I have used the term "Bushman" rather than "San" since it is now again widely in use, as is evident from recent titles in my bibliography. The term /Xam has been used when referring to the particular group of now extinct Cape Bushmen. Instead of Bleek's and Schultze's use of "Hottentot", the less offensive and widely accepted word "Khoi" has been used. The word "Nama" is more geographically limiting as it refers to groupings of Khoi people to the north and south of the Orange River.

${ }^{2}$ See "Wilhelm Bleek and the reconstruction of the Native Erotic Imagination: a study of censorship, genocide and colonial science", seminar paper presented at a SANPAD Colloquium, UWC, November 2010.

${ }^{3}$ For a fuller discussion of Bleek's awkwardness regarding sexual matters see Andrew Bank's comprehensive study Bushmen in a Victorian World: The Remarkable Story of the Bleek-Lloyd Collection of Bushman Folklore (2006:98).

${ }^{4}$ The biographical information about Schultze is inferred from the prefaces of several of his publications, as well as a short biographical entry in Thomas Adam's book Germany and the Americas: culture, politics and history (2005: 950).
} 